\title{
Aluminosilicate clay improves production responses and reduces inflammation during an aflatoxin challenge in lactating Holstein cows
}

\author{
R. T. Pate, ${ }^{*}$ D. M. Paulus Compart, $\dagger$ and F. C. Cardoso*1 \\ *Department of Animal Sciences, University of Illinois, Urbana 61801 \\ †PMI Nutritional Additives, Arden Hills, MN 55126
}

\begin{abstract}
Mitigation strategies are vital in minimizing the health and economic risks associated with dairy cattle exposure to aflatoxin (AF). The objective of this study was to determine the effects of a commercially available aluminosilicate clay in a lactation diet on production responses, blood chemistry, and liver inflammatory markers of multiparous lactating Holstein cows during an AF challenge. Sixteen multiparous lactating Holstein cows [body weight $($ mean $\pm \mathrm{SD})=758 \pm 76$ $\mathrm{kg}$; days in milk $=157 \pm 43 \mathrm{~d}$ ] were assigned to 1 of 4 treatments in a replicated $4 \times 4$ Latin square design with 21-d periods: no adsorbent and no AF challenge (CON), no adsorbent and an AF challenge (POS), 113 $\mathrm{g}$ of aluminosilicate clay top-dressed on the total mixed ration (adsorbent; FloMatrix, PMI Nutritional Additives, Arden Hills, MN) with an AF challenge (F4), or $227 \mathrm{~g}$ of adsorbent with an AF challenge (F8). The challenge consisted of $100 \mu \mathrm{g}$ of $\mathrm{AFB}_{1} / \mathrm{kg}$ of dietary dry matter intake administered orally. For each period, milk was sampled $3 \times$ daily from d 14 to 21; blood, feces, and urine were sampled on d 14, 18, and 21; and liver samples were taken on d 18. Liver tissue was assessed for gene expression and histological hepatocyte inflammation. Statistical analysis was preformed using the MIXED and GLIMMIX procedures of SAS (SAS Institute Inc., Cary, NC). Fat-corrected milk (POS = $37.2, \mathrm{~F} 4=39.2$, and $\mathrm{F} 8=38.9 \mathrm{~kg} / \mathrm{d}$ ) increased as concentration of adsorbent in the diet increased. There was a decrease in milk $\mathrm{AFM}_{1}$ concentration at d 18 as concentration of adsorbent in the diet increased (POS $=0.33, \mathrm{~F} 4=0.32$, and $\mathrm{F} 8=0.27 \mu \mathrm{g} / \mathrm{kg}$ ). There was a decrease in $\mathrm{AFM}_{1}$ concentration in urine (POS = $2.10, \mathrm{~F} 4=1.89$, and $\mathrm{F} 8=1.78 \mu \mathrm{g} / \mathrm{kg})$ and $\mathrm{AFB}_{1}$ concentration in feces $(\mathrm{POS}=4.68, \mathrm{~F} 4=3.44$, and $\mathrm{F} 8=$ $3.17 \mu \mathrm{g} / \mathrm{kg}$ ) as concentration of adsorbent in the diet
\end{abstract}

Received May 6, 2018.

Accepted August 23, 2018.

${ }^{1}$ Corresponding author: cardoso2@illinois.edu increased. Cows in CON had greater concentrations of serum cholesterol $(202 \mathrm{mg} / \mathrm{dL})$ and plasma superoxide dismutase $(2.8 \mathrm{U} / \mathrm{mL})$ compared with cows in POS (196 mg/dL and $2.6 \mathrm{U} / \mathrm{mL}$, respectively). Plasma glutamate dehydrogenase increased as concentration of adsorbent in the diet increased $(\mathrm{POS}=37.8, \mathrm{~F} 4=$ 39.3 , and $\mathrm{F} 8=39.1 \mathrm{U} / \mathrm{L})$. The expression of $N F K B 1$ was greater in the liver of cows in POS (0.78) compared with cows in CON (0.70). The expression of MTOR was greater in the liver of cows in CON (1.19) compared with cows in POS (0.96). When compared with cows in CON, cows in POS had greater odds ratio for hepatocyte inflammation (odds ratio $=5.14$ ). In conclusion, the adsorbent used in this study had a positive effect on milk production and hepatocyte inflammation and reduced AF transfer.

Key words: aflatoxin, liver, adsorbent, hepatocyte

\section{INTRODUCTION}

It is estimated that $25 \%$ of agricultural crops are affected by aflatoxins (AF), with corn being the primary crop of concern within the United States (FAO, 2004; Mitchell et al., 2016). Mitigation strategies are vital in minimizing the health and economic risks associated with dairy cattle exposure to AF. Producers often implement preharvest strategies to reduce the appearance of AF in their feedstuffs. These strategies include the selection of Aspergillus sp. resistant seed strains, implementation of crop rotations, and the use of foliar fungicides or inoculants before the ensiling process (Betrán et al., 2005; Kabak et al., 2006; Haerr et al., 2015; Kalebich and Cardoso, 2017). However, despite mitigation practices implemented by producers, AF can still cause a host of issues for humans and dairy cattle. Therefore, the US Food and Drug Administration (FDA) has enforced regulations on $\mathrm{AFM}_{1}$ concentrations in milk for human consumption and total $\mathrm{AF}\left(\mathrm{B}_{1}\right.$, $\mathrm{B}_{2}, \mathrm{G}_{1}$, and $\mathrm{G}_{2}$ ) in animal feed to not exceed 0.5 and 20 $\mu \mathrm{g} / \mathrm{kg}$, respectively, in the United States (FDA, 1994). In the European Union, the regulations are stricter: $\mathrm{AFM}_{1}$ concentrations in milk and total AF $\left(\mathrm{B}_{1}, \mathrm{~B}_{2}\right.$, 
$\mathrm{G}_{1}$, and $\mathrm{G}_{2}$ ) in feed cannot exceed 0.05 and $4 \mu \mathrm{g} / \mathrm{kg}$, respectively (European Commission, 2006).

Short-term exposure of AF to cattle causes a multitude of health problems. These problems include, but are not limited to, inappetence, lethargy, and reproductive disorders. Additionally, long-term exposure can be increasingly detrimental and may decrease milk production and feed efficiency, inhibit vaccine-induced immune function, and cause jaundice (Applebaum et al., 1982; Sulzberger et al., 2017). Aflatoxins are also considered toxic due to their carcinogenic effects on hepatocytes and their role in immunosuppression (Whitlow and Hagler, 2005; Shrestha and Mridha, 2015). Abrar et al. (2013) discussed that AF toxicity results from the generation of reactive oxygen species, such as superoxide anion and hydrogen peroxide, which lead to AF metabolites adhering to DNA, RNA, intracellular membranes, and proteins. Additionally, AF exposure can lead to an increase in inflammatory-related enzymes as well as increased hepatic gene expression of proteins related to inflammatory response mechanisms, including NFKB1 and GPX1 (Bernabucci et al., 2011; Shi et al., 2016; Weatherly et al., 2018; Pate and Cardoso, 2018).

To reduce the effect of $\mathrm{AF}$ on cattle health, sequestering agents such as aluminosilicate clays may be added to the diet. Sequestering agents, or adsorbents, have been proven to limit AF bioavailability through ion exchange, leading to decreased $\mathrm{AF}$ concentrations in milk (Moschini et al., 2008). Additionally, lactating Holstein cows fed bentonite clay, an AF adsorbent, concomitantly with Saccharomyces cerevisiae had improved production responses (i.e., milk yield) during an AF challenge than cows not receiving the adsorbent (Jiang et al., 2018). Ogunade et al. (2016) evaluated the immune system response of supplementing mycotoxin-sequestering agents to cows during an $\mathrm{AFB}_{1}$ challenge. In that study, a greater mean fluorescent intensity of staining was reported for 2 leukocyte adhesion molecules, L-selectin and $\beta$-integrin, on neutrophils of cows fed diets containing yeast cell culture or sodium bentonite. Blood neutrophils are the first line of defense in the innate immune system, and the greater adhesion molecule florescence suggested a migration of neutrophils to the exposed toxin during challenge (Silvestre et al., 2011; Ogunade et al., 2016). This indicated an improved immune response to $\mathrm{AFB}_{1}$ when adsorbents were included in the diet. Similarly, cows fed clay and challenged with $\mathrm{AF}$ tended to have lower plasma superoxide dismutase (SOD) concentrations, possibly indicating less oxidative stress when an adsorbent was fed (Sulzberger et al., 2017).

Therefore, the objective of this study was to determine the effects of a commercially available alumino- silicate clay in a traditional lactation diet during an $\mathrm{AF}$ challenge on the presence of $\mathrm{AFM}_{1}$ in milk and urine, $\mathrm{AFB}_{1}$ in feces, production responses, blood chemistry, and liver inflammatory markers of multiparous lactating Holstein cows.

\section{MATERIALS AND METHODS}

\section{Animal Care and Housing}

The University of Illinois (Urbana-Champaign) Institutional Animal Care and Use Committee approved all experimental procedures (no. 17038). The experimental period transpired from March 2017 to May 2017. Cows were fed ad libitum for a 5\% minimum refusal and had constant access to water. Diet (TMR) was formulated according to NRC (2001) recommendations (Table 1) based on cows at 180 DIM, $703 \mathrm{~kg}$ of BW, producing 32 $\mathrm{kg}$ of milk/d with a target $3.8 \%$ milk fat and $3.3 \%$ milk protein, and a predicted DMI of $25 \mathrm{~kg} / \mathrm{d}$.

\section{Experimental Design and AF Challenge Procedure}

A total of 16 multiparous lactating Holstein cows $[\mathrm{BW}($ mean $\pm \mathrm{SD})=758 \pm 76 \mathrm{~kg} ; \mathrm{DIM}=157 \pm 43$

Table 1. Ingredient composition of the diet fed to all cows during the experimental period

\begin{tabular}{lc}
\hline Ingredient & \% of DM \\
\hline Corn silage $^{1}$ & 37.44 \\
Canola meal & 12.72 \\
Alfalfa hay & 11.31 \\
Corn gluten feed & 4.94 \\
Soy hulls & 4.30 \\
Wheat straw & 2.34 \\
Dry ground corn grain & 20.40 \\
Blood meal & 1.89 \\
Rumen protected lysine & 3 \\
Rumen protected methionine & 0.62 \\
Potassium carbonate & 0.15 \\
Sodium bicarbonate & 0.20 \\
Calcium & 1.22 \\
Potassium chloride & 1.09 \\
Urea $46 \%_{\text {Salt, white }}$ & 0.44 \\
Magnesium oxide $54 \%$ & 0.33 \\
Vitamin and mineral mix & \\
\end{tabular}

${ }^{1}$ All treatments fed at $34.7 \%$ corn silage DM.

${ }^{2}$ ProVAAl AADvantage (Perdue AgriBusiness, Salisbury, MD).

${ }^{3}$ Ajipro-L Generation 2 (Ajinimoto Heartland Inc., Chicago, IL).

${ }^{4}$ Smartamine M (Adisseo, Alpharetta, GA).

${ }^{5}$ Vitamin and mineral mix was formulated to contain $12.51 \% \mathrm{Ca}$, $14.06 \% \mathrm{Na}, 9.60 \% \mathrm{Cl}, 3.18 \% \mathrm{Mg}, 6.48 \% \mathrm{~K}, 0.19 \% \mathrm{~S}, 26.93 \mathrm{mg} / \mathrm{kg}$ of $\mathrm{Co}, 301.01 \mathrm{mg} / \mathrm{kg}$ of $\mathrm{Cu}, 40.22 \mathrm{mg} / \mathrm{kg}$ of I, $678.25 \mathrm{mg} / \mathrm{kg}$ of Fe, $1,519.35 \mathrm{mg} / \mathrm{kg}$ of Mn, $8.62 \mathrm{mg} / \mathrm{kg}$ of Se, $4.47 \mathrm{mg} / \mathrm{kg}$ of organic Se, $1,621.05 \mathrm{mg} / \mathrm{kg}$ of $\mathrm{Zn}, 43.34 \mathrm{kIU} / \mathrm{kg}$ of vitamin $\mathrm{A}, 10.89 \mathrm{kIU} / \mathrm{kg}$ of vitamin $\mathrm{D}_{3}, 466.41 \mathrm{IU} / \mathrm{kg}$ of vitamin $\mathrm{E}, 4.23 \mathrm{mg} / \mathrm{kg}$ of biotin, 46.65 $\mathrm{mg} / \mathrm{kg}$ of thiamine, and $0.35 \mathrm{~g} / \mathrm{kg}$ of monensin (Rumensin, Elanco, Greenfield, IN). 
d] were assigned to 1 of 4 treatments in a replicated $4 \times 4$ Latin square design balanced to measure carryover effects. Periods $(21 \mathrm{~d})$ were separated into an adaptation phase (d 1-13) and a measurement phase (d 14-21). From d 15 to 17 , cows received an AF challenge comparable with the one offered by Kutz et al. (2009). The Veterinary Medical Diagnostic Laboratory, College Veterinary Medicine, University of Missouri, Columbia, provided the dietary AF, which was made of Aspergillus parasiticus (NRRL-2999) culture material containing $102 \mathrm{mg} / \mathrm{kg}$ of $\mathrm{AFB}_{1}, 3.5 \mathrm{mg} / \mathrm{kg}$ of $\mathrm{AFB}_{2}, 35 \mathrm{mg} / \mathrm{kg}$ of $\mathrm{AFG}_{1}$, and $0.9 \mathrm{mg} / \mathrm{kg}$ of $\mathrm{AFG}_{2}$. The challenge consisted of $100 \mu \mathrm{g}$ of $\mathrm{AFB}_{1} / \mathrm{kg}$ of dietary DMI administered orally in 28-mL gelatin capsules (Structure Probe Inc., West Chester, PA) via balling gun immediately after feeding. Aflatoxin $\mathrm{B}_{1}$ allocation was determined based on the individual average DMI from d 12 to 14 . Treatments were no adsorbent and no AF challenge $(\mathbf{C O N})$, no adsorbent and an AF challenge (POS), 113 $\mathrm{g}$ of aluminosilicate clay (adsorbent; FloMatrix, PMI Nutritional Additives, Arden Hills, MN) with an AF challenge (F4), or $227 \mathrm{~g}$ of adsorbent with an AF challenge (F8). One treatment contrast (POS vs. CON) was compared along with linear and quadratic treatment effects (POS, F4, and F8). The same TMR was fed to all cows once daily at $0700 \mathrm{~h}$ throughout the trial period. The daily adsorbent allocation for F4 and F8 was mixed with $300 \mathrm{~g}$ of ground corn and top dressed onto the TMR immediately after feeding. Cows in POS and CON were administered a top dress consisting of $300 \mathrm{~g}$ of ground corn immediately after feeding.

\section{Data Collection and Sampling Procedures}

Samples of TMR (Table 2) were obtained weekly and analyzed for DM (AOAC International, 1995a) by drying in a forced-air oven at $110^{\circ} \mathrm{C}$ for $24 \mathrm{~h}$. Diet composition was adjusted weekly for DM content changes of ingredients. The daily TMR offered and refused was recorded from each cow to determine intake based on weekly DM analyses. Total mixed ration samples were collected weekly (3 per period) and stored at $-20^{\circ} \mathrm{C}$ until analyzed. Composite samples for each period $(\mathrm{n}=$ 4) were analyzed for contents of DM, CP, ADF, NDF, lignin, NFC, starch, fat, ash, TDN, $\mathrm{Ca}, \mathrm{P}, \mathrm{Mg}, \mathrm{K}, \mathrm{Na}$, $\mathrm{Fe}, \mathrm{Zn}, \mathrm{Cu}, \mathrm{Mn}, \mathrm{Mo}$, and $\mathrm{S}$ using wet chemistry methods (Dairy One, Ithaca, NY; Table 2). Values for $\mathrm{NE}_{\mathrm{L}}$ were provided by the laboratory and were calculated based on NRC (2001). Additionally, 1 composite sample per period $(\mathrm{n}=4)$ was stored at $-20^{\circ} \mathrm{C}$ until being sent to the Veterinary Medical Diagnostic Laboratory, College of Veterinary Medicine, University of Missouri, Columbia, to be analyzed for AF concentrations. Physical characterization of the TMR, based on the Penn
State Particle Separator (Kononoff et al., 2003), was performed weekly.

Cows were milked $3 \times$ daily at 0600,1300 , and 2200 h. Milk weights were recorded at each milking, and milk samples were attained at each milking throughout the measurement phase. A preservative (800 Broad Spectrum Microtabs II; D\&F Control Systems Inc., San Ramon, CA) was added to the samples taken on d 15 and 17. Preserved samples were stored in a refrigerator at $8^{\circ} \mathrm{C}$, composited in proportion to milk yield at each milking, and sent to a commercial laboratory (Dairy Lab Services, Dubuque, IA). Milk samples were analyzed for contents of fat, true protein, MUN, lactose, and TS and for SCC using mid-infrared procedures (AOAC International, 1995b; Table 3). The appearance and disappearance of the $\mathrm{AFM}_{1}$ excreted in milk was tested at each milking during the measurement phase with the use of a SNAP AFM 1 test (Idexx, Westbrook, $\mathrm{ME}$; detection level of $0.5 \mu \mathrm{g}$ of $\mathrm{AFM}_{1} / \mathrm{kg}$ of milk). On d 14, 18, and 21, milk samples were stored at $-20^{\circ} \mathrm{C}$ until they were composited by day and sent to the Veterinary Medical Diagnostic Laboratory, College Veterinary Medicine, University of Missouri, Columbia, to be analyzed for $\mathrm{AFM}_{1}$ concentrations by HPLC with fluorescence detection methods as described by Kutz et al. (2009; Table 4).

Urine samples $(60 \mathrm{~mL})$ were collected at $0730 \mathrm{~h}$ on d 14,18 , and 21 via manual stimulation of urination. Fecal samples (400 g, wet weight) were collected on d 14, 18, and 21 directly from the cow's rectum. Fresh urine

Table 2. Mean chemical composition and associated SD for diets fed to all cows throughout the experimental period

\begin{tabular}{|c|c|c|}
\hline Item & Mean $^{1}$ & $\mathrm{SD}$ \\
\hline DM, \% & 48.6 & 1.04 \\
\hline $\mathrm{CP}, \%$ of $\mathrm{DM}$ & 17.1 & 0.17 \\
\hline $\mathrm{ADF}, \%$ of $\mathrm{DM}$ & 19.4 & 0.67 \\
\hline $\mathrm{NDF}, \%$ of $\mathrm{DM}$ & 31.8 & 0.59 \\
\hline Lignin, \% of DM & 3.5 & 0.19 \\
\hline NFC, $\%$ of DM & 38.4 & 1.08 \\
\hline Starch, $\%$ of DM & 33.4 & 2.16 \\
\hline Crude fat, $\%$ of DM & 3.8 & 0.19 \\
\hline Ash, $\%$ of DM & 8.97 & 0.87 \\
\hline $\mathrm{NE}_{\mathrm{L}},{ }^{2} \mathrm{Mcal} / \mathrm{kg}$ of $\mathrm{DM}$ & 0.74 & 0.01 \\
\hline $\mathrm{Ca}, \%$ of $\mathrm{DM}$ & 1.24 & 0.51 \\
\hline $\mathrm{P}, \%$ of $\mathrm{DM}$ & 0.42 & 0.02 \\
\hline $\mathrm{Mg}, \%$ of $\mathrm{DM}$ & 0.33 & 0.02 \\
\hline $\mathrm{K}, \%$ of $\mathrm{DM}$ & 1.50 & 0.09 \\
\hline $\mathrm{Na}, \%$ of $\mathrm{DM}$ & 0.35 & 0.03 \\
\hline $\mathrm{S}, \%$ of $\mathrm{DM}$ & 0.28 & 0.01 \\
\hline $\mathrm{Fe}, \mathrm{mg} / \mathrm{kg}$ & 387 & 104.32 \\
\hline $\mathrm{Zn}, \mathrm{mg} / \mathrm{kg}$ & 88 & 4.21 \\
\hline $\mathrm{Cu}, \mathrm{mg} / \mathrm{kg}$ & 16 & 0.83 \\
\hline $\mathrm{Mn}, \mathrm{mg} / \mathrm{kg}$ & 85 & 15.25 \\
\hline $\mathrm{Mo}, \mathrm{mg} / \mathrm{kg}$ & 0.9 & 0.26 \\
\hline
\end{tabular}

${ }^{1}$ Mean diet composition of periods $1,2,3$, and $4(\mathrm{n}=4)$.

${ }^{2} \mathrm{NRC}(2001)$. 
Table 3. Least squares means and associated SEM for BW, BCS, and production parameters of Holstein cows during wk 3 of each period (measurement phase)

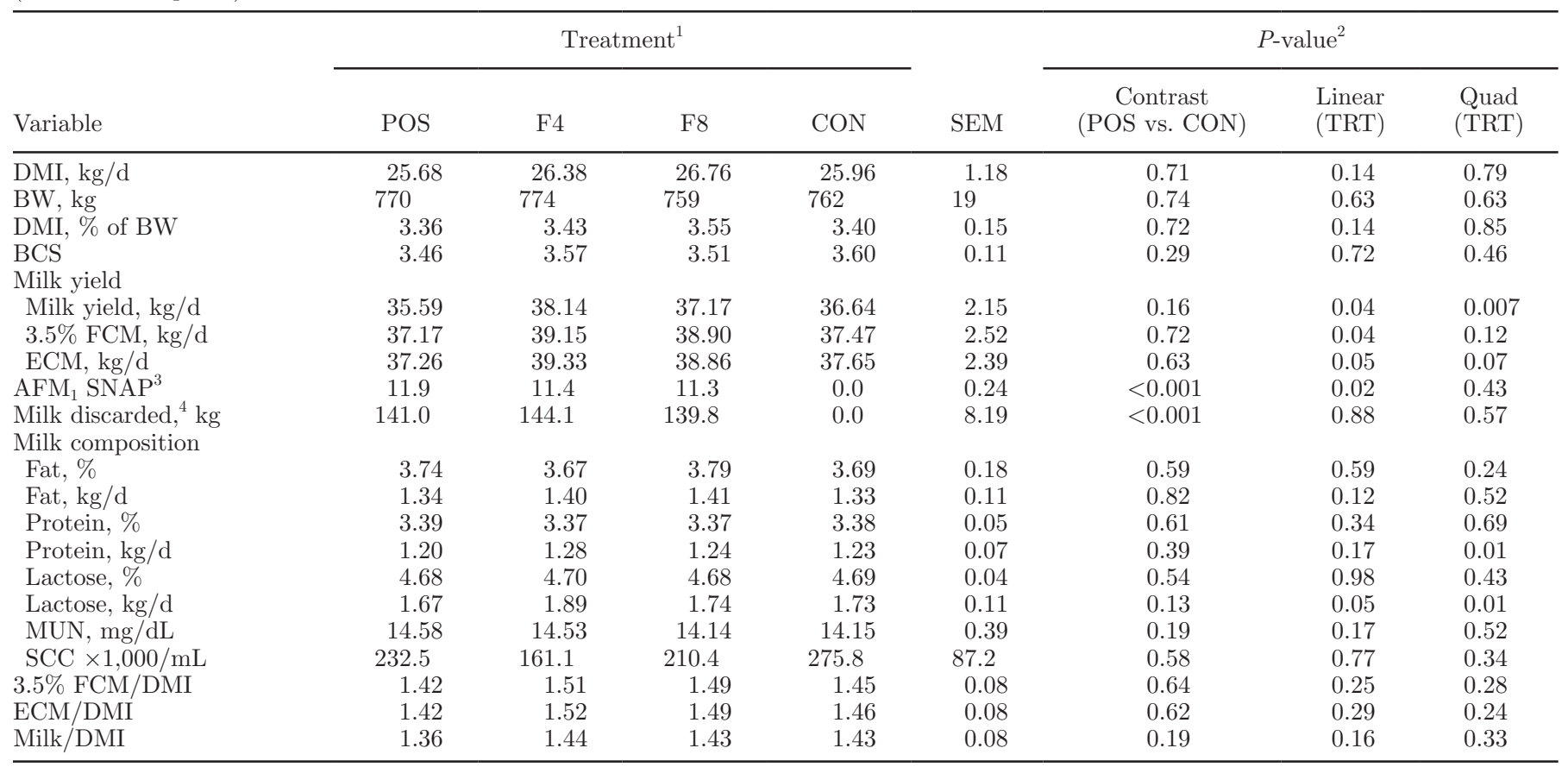

${ }^{1}$ Dietary treatments were positive control diet [POS; without adsorbent $(0 \mathrm{~g})$ and with aflatoxin (AF) challenge], $113 \mathrm{~g}$ of adsorbent in diet (F4; with $113 \mathrm{~g}$ of adsorbent in a top dress), $227 \mathrm{~g}$ of adsorbent in diet (F8; with $227 \mathrm{~g}$ of adsorbent in a top dress), and negative control diet (CON; without adsorbent and no AF challenge). Top dress vehicle was $300 \mathrm{~g}$ of ground corn. Aflatoxin challenge: $100 \mu \mathrm{g}$ of $\mathrm{AF} / \mathrm{kg}$ of DMI of contaminated corn, based on average DMI of the last $3 \mathrm{~d}$ before the challenge.

${ }^{2}$ Contrasts were 1 = POS compared with CON; linear and quadratic effects of treatments (TRT) POS (0 g), F4 (113 g of adsorbent), and F8 (227 g of adsorbent).

${ }^{3}$ Number of milkings with a positive SNAP test (Idexx, Westbrook, ME).

${ }^{4}$ Total amount of milk discarded during the challenge week.

Table 4. Least squares means and associated SEM for aflatoxin concentrations in milk, urine, and feces, and total bacteria counts in urine of Holstein cows during wk 3 of each period (measurement phase)

\begin{tabular}{|c|c|c|c|c|c|c|c|c|}
\hline \multirow[b]{2}{*}{ Variable } & \multicolumn{4}{|c|}{ Treatment $^{1}$} & \multirow[b]{2}{*}{ SEM } & \multicolumn{3}{|c|}{$P$-value } \\
\hline & POS & $\mathrm{F} 4$ & F8 & $\mathrm{CON}$ & & $\begin{array}{c}\text { Contrast } \\
\text { (POS vs. CON) }\end{array}$ & $\begin{array}{l}\text { Linear } \\
\text { (TRT) }\end{array}$ & $\begin{array}{l}\text { Quad } \\
\text { (TRT) }\end{array}$ \\
\hline Milk $\mathrm{AFM}_{1} \mathrm{~d} 18,{ }^{3} \mu \mathrm{g} / \mathrm{kg}$ & 0.33 & 0.32 & 0.27 & 0.00 & 0.02 & $<0.001$ & 0.001 & 0.30 \\
\hline $\mathrm{AFM}_{1}$ excretion, ${ }^{4} \mu \mathrm{g} / \mathrm{d}$ & 11.6 & 12.4 & 10.8 & 0.00 & 1.09 & $<0.001$ & 0.47 & 0.20 \\
\hline $\mathrm{AFM}_{1}$ transfer, ${ }^{5} \%$ & 0.45 & 0.49 & 0.39 & 0.00 & 0.04 & $<0.001$ & 0.11 & 0.03 \\
\hline Urine bacteria, ${ }^{6} \mathrm{cfu} \times 1,000$ & 52.5 & 43.8 & 59.0 & 9.0 & 26.78 & 0.34 & 0.84 & 0.49 \\
\hline
\end{tabular}

${ }^{1}$ Dietary treatments (TRT) were positive control diet [POS; without adsorbent $(0 \mathrm{~g})$ and with aflatoxin (AF) challenge], $113 \mathrm{~g}$ of adsorbent in diet (F4; with $113 \mathrm{~g}$ of adsorbent in a top dress), $227 \mathrm{~g}$ of adsorbent in diet (F8; with $227 \mathrm{~g}$ of adsorbent in a top dress), and negative control diet (CON; without adsorbent and no AF challenge). Top dress vehicle was $300 \mathrm{~g}$ of ground corn. Aflatoxin challenge: $100 \mu \mathrm{g}$ of AF/kg of DMI of contaminated corn, based on average DMI of the last $3 \mathrm{~d}$ before the challenge.

${ }^{2}$ Samples that were analyzed were collected on d 14, 18, and 21 of each period. TRT $\times$ day for milk, feces, and urine $(P<0.001)$.

${ }^{3}$ Samples that were analyzed were collected on d 18 of each period.

${ }^{4} \mathrm{AFM}_{1}$ excretion $=\mathrm{AFM}_{1}(\mu \mathrm{g})$ concentration in milk on $\mathrm{d} 18 \times$ milk yield on d $18(\mathrm{~kg})$. Calculations were done solely on $\mathrm{d} 18$ to demonstrate the effectiveness at the highest concentration of $\mathrm{AFM}_{1}$ in the milk. CON $=35.57 \mathrm{~kg}$, POS $=34.80 \mathrm{~kg}, \mathrm{~F} 4=38.16 \mathrm{~kg}, \mathrm{~F} 8=38.74 \mathrm{~kg}$; $\mathrm{SEM}=$ $10.54 \mathrm{~kg}$.

${ }^{5} \mathrm{AFM}_{1}$ transfer $=[\mathrm{AFM}$ excretion $(\mu \mathrm{g} / \mathrm{d}) / \mathrm{AFM}$ intake $(\mu \mathrm{g} / \mathrm{d})] \times 100$.

${ }^{6} \mathrm{~A}$ day effect for total bacteria count was present $(P<0.05$; Figure 5$)$. 
samples $(5 \mathrm{~mL})$ were sent to the University of Illinois Veterinary Diagnostic Laboratory for total bacteria count on d 14 and 18. Urine and fecal samples were stored at $-20^{\circ} \mathrm{C}$ until they were sent to the Veterinary Medical Diagnostic Laboratory, College Veterinary Medicine, University of Missouri, Columbia, to be analyzed for $\mathrm{AFB}_{1}$ and $\mathrm{AFM}_{1}$ concentrations (Table 4). Before analysis, feces were thawed and dried in a forced-air oven at $55^{\circ} \mathrm{C}$ for $72 \mathrm{~h}$, and then samples were ground (Wiley mill, Thomas Scientific, Swedesboro, NJ) through a 1-mm screen. Additionally, a subset of dried fecal samples was composited by period $(\mathrm{n}=4)$ and sent to a commercial laboratory (Dairy Lab Services) to be analyzed for fecal starch.

Blood samples were taken from the coccygeal vein or artery at $0730 \mathrm{~h}$ on $\mathrm{d} 14,18$, and $21(\mathrm{n}=3)$ of each period from each cow (BD Vacutainer, Becton Dickinson, Franklin Lakes, NJ). Serum and plasma samples were attained via centrifugation of the tubes at $2,500 \times g$ for $15 \mathrm{~min}$ at $4^{\circ} \mathrm{C}$ and stored at $-80^{\circ} \mathrm{C}$ until further analysis was conducted. $\beta$-Hydroxybutyrate was analyzed from whole blood immediately after sampling using a digital cow-side ketone monitor (Nova Max Plus, Nova Biomedical Corp., Waltham, MA). Heparinized plasma samples were sent to the University of Illinois Veterinary Diagnostic Laboratory to be analyzed for bovine chemistry profiles (BUN, albumin, glutamate dehydrogenase, alanine aminotransferase, and $\gamma$-glutamyl transferase) using the AU680 Beckman Coulter analyzer (http://vetmed.illinois.edu/vet -resources/veterinary-diagnostic-laboratory/clinical -pathology/). Commercially available assay kits were used to analyze heparinized plasma samples for glucose, SOD activity, glutathione peroxidase (GSH-Px) activity, serum amyloid A (SAA), and lipopolysaccharide binding protein (LBP). Plasma glucose was assessed using the Glucose Autokit assay (Wako Pure Chemical Industries Ltd., Mountain View, CA). Serum cholesterol was assessed using the Cholesterol E assay (Wako Pure Chemical Industries Ltd.) following the manufacturer's instructions. Plasma SOD activity was assessed using a Superoxide Dismutase assay kit that measured the dismutation of superoxide radicals produced by xanthine oxidase and hypoxanthine (Cayman Chemical, Ann Arbor, MI) following the manufacturer's instructions. Plasma GSH-Px activity was measured using the Glutathione Peroxidase assay kit with an indirect enzymatic recycling method, using glutathione reductase for the quantification of glutathione reduction by GSH-Px (Cayman Chemical) following the manufacturer's instructions. Serum amyloid A was assessed using the Phase Range Multispecies SAA ELISA kit (Tridelta Development Ltd., Maynooth, Ireland) following the manufacturer's instructions. Plasma LBP was assessed using the Human Lipopolysaccharide Binding Protein Multispecies Reactive ELISA kit (Cell Sciences, Newburyport, MA) following the manufacturer's instructions.

Liver biopsies were performed on d 18 of each period using a similar technique to that described in Pate and Cardoso (2018). Briefly, an 18-gauge $\times 10.2-\mathrm{cm}$ bone marrow probe (Monoject-8881247087, Medtronic, Fridley, MN), was used to obtain approximately $2 \mathrm{~g}$ (wet weight) of liver sample. Liver samples were snap-frozen and stored in liquid nitrogen until further analysis.

Evaluations of health, fecal scoreBW (digital scale, model CW-11, Ohaus, Newark, NJ), and BCS [assigned in quarter-unit increments weekly for each cow (Ferguson et al., 1994) by more than 1 person independently at each time of scoring; the average score was used for statistical analysis] were performed throughout the measurement phase as described in Pate and Cardoso (2018).

\section{Hepatic Gene Expression}

Complete details of the procedures are included in the Supplemental Materials (https://doi.org/10.3168/ jds.2018-15024). Briefly, total RNA was extracted and used for cDNA synthesis. Real-time quantitative PCR performed was SYBR Green-based, using a 6-point standard curve. The extraction and quantitative PCR analysis were preformed using previously established protocols at the University of Illinois (Riboni et al., 2015). Nine genes were selected for transcript profiling in liver tissue: albumin $(A L B)$, cytochrome $\mathrm{P} 450$ 1A2 (CYP1A2), glutamate dehydrogenase ( $\boldsymbol{G L} \boldsymbol{U D} \mathbf{D})$, haptoglobin $(H P)$, malate dehydrogenase (MDH2), mechanistic target of rapamycin (MTOR), nuclear factor $\kappa \beta$ (NFKB1), signal transducer and activator of transcription (STAT5A), and tumor necrosis factor $\alpha(\boldsymbol{T N F A})$. All primers were designed for the current experiment (Integrated DNA Technologies, Coralville, IA). The final data were normalized using the geometric mean of 3 internal control genes: GAPDH, RPS9, and UXT (Khan et al., 2015).

\section{Histological Hepatocyte Inflammation Evaluation}

Histological hepatocyte inflammation was assessed for liver tissue collected on d 18 of each period. Approximately $0.1 \mathrm{~g}$ (wet weight) of fresh liver sample was immediately placed in $1.5 \mathrm{~mL}$ of formalin for 24 $\mathrm{h}$ before being transferred to $70 \%$ ethanol and sent to the University of Illinois Veterinary Diagnostic Laboratory for paraffin embedding and hematoxylin and eosin staining. Evaluations were conducted on 5 subsections of each sample $(\mathrm{n}=64)$ at $40 \times$ magnification. A hepatic 

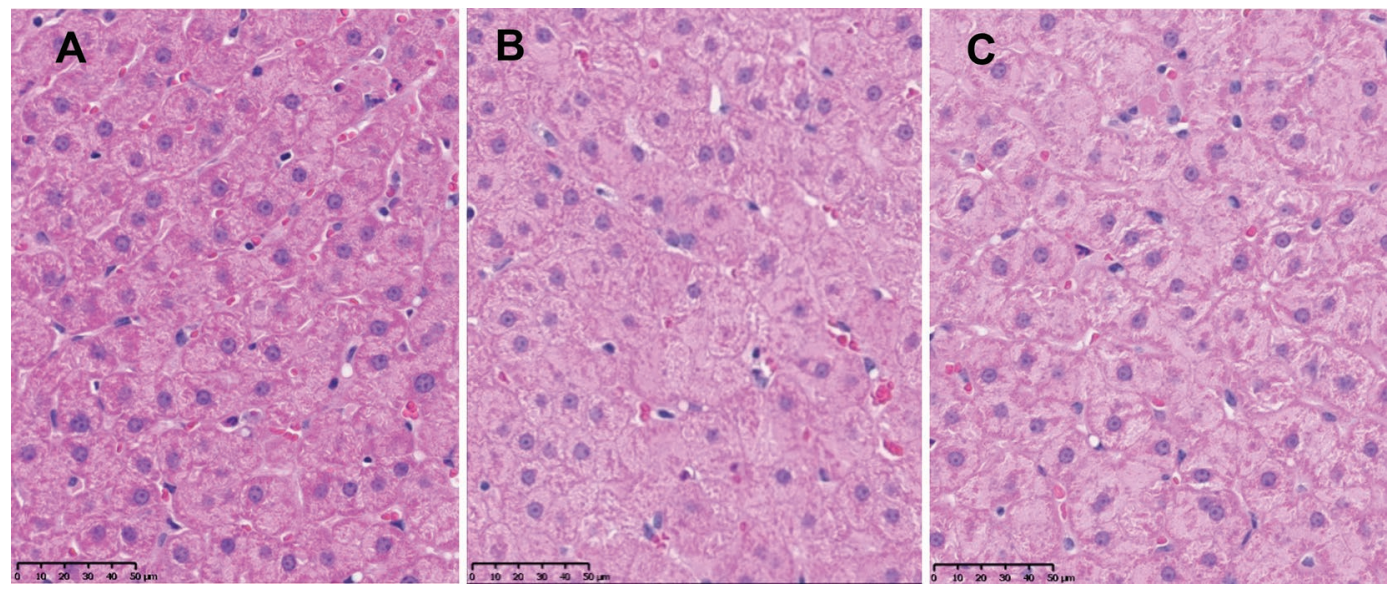

Figure 1. Hepatocyte tissue samples were taken at d 18 of each period, embedded in paraffin, and stained with hematoxylin and eosin. Hepatocyte inflammation scores were determined for 5 subsections of each sample at $40 \times$ magnification based on the following 0 -to- 2 scale: (A) score $0=$ no hepatocytes exhibiting gray pallor or swelling; (B) score $1=$ less than $50 \%$ of the hepatocytes exhibiting gray pallor or swelling; (C) score $2=$ greater than $50 \%$ of the hepatocytes exhibiting gray pallor or swelling. Scale bar $=50 \mu \mathrm{m}$.

activity score was used to evaluate hepatocyte inflammation, similar to methods described by Ishak et al. (1995): score $0=$ no hepatocytes exhibiting gray pallor or swelling; score $1=$ less than $50 \%$ of hepatocytes exhibiting gray pallor or swelling; score $2=$ greater than $50 \%$ of hepatocytes exhibiting gray pallor or swelling (Figure 1). Hepatic activity score was categorized at the median concentration value of score 1.25 as high or low. Even though dichotomization can reduce total information, this strategy allowed for exploration of the nonlinear association of hepatic activity scores that have reduced variation (Ishak et al., 1995).

\section{AF Calculations}

Aflatoxin $\mathrm{M}_{1}$ excretion in milk ( $\mu \mathrm{g} / \mathrm{kg}$ ) was calculated in comparison with Maki et al. (2016) using the following equations: excretion $(\mu \mathrm{g} / \mathrm{kg})=$ concentration of $\mathrm{AFM}_{1}$ in milk on d $18(\mu \mathrm{g}) \times$ milk yield on d $18(\mathrm{~kg})$, and $\mathrm{AF}$ transfer $(\%)=\left[\mathrm{AF}\right.$ excretion $(\mu \mathrm{g} / \mathrm{kg}) / \mathrm{AFB}_{1}$ challenge $(\mu \mathrm{g} / \mathrm{kg})] \times 100$.

\section{Statistical Analyses}

Data collected from d 14 to 21 of each period were analyzed using SAS (v. 9.4, SAS Institute Inc., Cary NC). The MIXED procedure of SAS was used for production variables to model the fixed effects of treatment, square, and period:

$$
\mathrm{Y}_{\mathrm{ijk}}=\mu+\mathrm{T}_{\mathrm{i}}+\mathrm{S}_{\mathrm{j}}+\mathrm{P}_{\mathrm{k}}+\varepsilon_{\mathrm{ijk}}
$$

where $Y_{\mathrm{ijk}}=$ the observations for dependent variables; $\mu=$ the overall mean; $T_{i}=$ the fixed effect of the ith treatment; $S_{j}=$ the effect of the jth square; $P_{k}=$ the effect of the kth period; and $\varepsilon_{\mathrm{ijk}}=$ the random residual error. For variables with measurement over time, the MIXED procedure of SAS was used to model the fixed effects of treatment, day, treatment $\times$ day interaction, square, and period using the following model:

$$
\mathrm{Y}_{\mathrm{ijkl}}=\mu+\mathrm{T}_{\mathrm{i}}+\mathrm{D}_{\mathrm{j}}+\mathrm{T}_{\mathrm{i}} \times \mathrm{D}_{\mathrm{j}}+\mathrm{S}_{\mathrm{k}}+\mathrm{P}_{\mathrm{l}}+\varepsilon_{\mathrm{ijkl}},
$$

where $Y_{\mathrm{ijkl}}=$ the observations for dependent variables; $=$ the overall mean; $\mathrm{T}_{\mathrm{i}}=$ the fixed effect of the ith treatment; $D_{j}=$ the repeated measurement (day) effect; $T_{i} \times D_{j}=$ the interaction of treatment and repeated measurement; $S_{k}=$ the effect of the kth square; $\mathrm{P}_{1}=$ the effect of the lth period; and $\varepsilon_{\mathrm{ijk}}=$ the random residual error. The estimation method was restrictive maximum likelihood, and the degrees of freedom method was Kenward-Roger (Littell, 2002). Variables were subjected to 5 covariance structures: compound symmetry, unstructured, autoregressive order 1, autoregressive heterogeneous order 1 , and Toeplitz. Compound symmetry was the covariance structure that yielded the lowest corrected Akaike information criterion and was used in the model (Littell, 2002). For both models, cow was the experimental unit and was considered as a random effect.

One orthogonal contrast was used along with the linear and quadratic effects of treatments POS, F4, and F8. The positive control treatment (no adsorbent and AF challenge) was compared with the negative control treatment (no adsorbent and no AF challenge). Values reported are least squares means and associated standard errors of the mean. Normality and homoscedasticity of residuals distribution was evaluated. Somatic 
cell count, plasma glutamate dehydrogenase, plasma LBP, and plasma SAA were log-transformed for better normality and homoscedasticity of residuals. Data presented for these variables were back-transformed. Frequency analysis was performed using the FREQ procedure of SAS considering the binary response variable SNAP test using the chi-squared probability. Finally, multivariable logistic mixed models (PROC GLIMMIX) considering the binary outcome variable and histological hepatocyte inflammation score were constructed. Treatments were forced into the models. Cow was considered as a random effect. Cows that developed illness $(\mathrm{n}=1 \mathrm{CON})$ during the measurement phase (d 14-21) were removed from the data set. Statistical significance was declared at $P \leq 0.05$ and trends were declared at $0.05<P \leq 0.10$.

\section{RESULTS}

\section{Diet Composition}

The ingredient composition of the experimental diet is shown in Table 1. Analyzed nutrient composition from the experimental diet is shown in Table 2. The physical characteristics of the TMR based on the Penn State Particle Separator (Kononoff et al., 2003) was (mean $\pm \mathrm{SD}$ ) $3.3 \pm 1.1 \%$ on upper sieves (19-mm pore size), $38.9 \pm 4.0 \%$ on middle sieves ( 8 -mm pore size), $13.5 \pm 1.8 \%$ on lower sieves (4-mm pore size), and 44.4 $\pm 5.0 \%$ in the pan. Fecal starch level for all periods (n $=4)$ was (mean $\pm \mathrm{SD}) 3.2 \pm 0.5 \% \mathrm{DM}$.

\section{DMI, BW, BCS, and Lactation Performance}

Performance data from the measurement phase are given in Table 3. There were no treatment differences for the contrast (POS vs. CON), linear, or quadratic effects for DMI, BW, DMI as a percentage of BW, or BCS. Milk yield exhibited linear and quadratic treatment effects $(P=0.04$ and 0.007 , respectively). Fat-corrected milk and ECM had positive linear treatment effects as concentration of adsorbent in the diet increased $(P=0.04$ and 0.05 , respectively). There were no treatment differences $(P>0.16)$ in feed efficiency (FCM/DMI, ECM/DMI, and milk yield/DMI) for the contrast (POS vs. CON), linear, or quadratic effects. Protein yield $(\mathrm{kg} / \mathrm{d})$ had a quadratic treatment effect $(P$ $=0.01)$. Lactose yield $(\mathrm{kg} / \mathrm{d})$ had linear and quadratic treatment effects $(P=0.05$ and 0.01 , respectively). The number of positive SNAP tests $\left(>0.5 \mu \mathrm{g}\right.$ of $\mathrm{AFM}_{1} / \mathrm{kg}$ of milk) and total milk discarded (landfill due to regulations by the FDA on $\mathrm{AFM}_{1}$ concentrations) was greater for cows in POS than cows in CON $(P<0.0001$ and $P$
$<0.0001$, respectively; POS vs. CON). The SNAP tests had a negative linear treatment effect, with the number of positive tests decreasing as the concentration of adsorbent in the diet increased $(P=0.02)$.

\section{AF Concentrations and Urine Total Bacteria Count}

Aflatoxin concentrations in TMR were below detection limits (10 $\mu \mathrm{g}$ of $\mathrm{AF} / \mathrm{kg}$ of TMR) for all periods (n =4). Aflatoxin $\mathrm{M}_{1}$ concentrations in milk and urine, $\mathrm{AFB}_{1}$ concentrations in feces, total bacteria count in urine, and $\mathrm{AFM}_{1}$ excretion and transference in milk data are in Table 4 . Treatment $\times$ day interactions for $\mathrm{AFM}_{1}$ concentration in milk, urine, and feces are shown in Figures 2, 3, and 4, respectively. Day effects for urine total bacteria count are shown in Figure 5. Milk $\mathrm{AFM}_{1}$ concentration, urine $\mathrm{AFM}_{1}$ concentration, and fecal $\mathrm{AFB}_{1}$ concentration were lower for cows in CON compared with cows in POS $(P<0.0001$; POS vs. CON $)$. On d 18, milk concentration, transfer rate, and excretion of $\mathrm{AFM}_{1}$ were lower for cows in CON compared with those in $\mathrm{POS}(P<0.0001$; POS vs. CON $)$. There were negative linear treatment effects for milk $\mathrm{AFM}_{1}$ concentration and milk $\mathrm{AFM}_{1}$ concentration at d 18 as concentration of adsorbent in the diet increased $(P=$ 0.02 and 0.001 , respectively). A quadratic treatment effect was present for $\mathrm{AFM}_{1}$ transference $(P=0.03)$. There was a negative linear treatment effect for $\mathrm{AFM}_{1}$ concentration in urine and feces as concentration of adsorbent in the diet increased $(P=0.04$ and 0.05 , respectively). Concentration of $\mathrm{AFM}_{1}$ in milk, urine, and feces had a treatment and a day effect $(P<0.0001$ and $P<0.0001$, respectively) as well as a treatment $\times$ day interaction $(P<0.0001)$. A day effect was present for total bacteria count in urine $(P<0.05)$.

\section{Serum and Plasma Chemistry Profile}

Serum and plasma chemistry profiles are shown in Table 5. Cows in CON had greater concentrations of serum cholesterol $(P<0.001)$ and plasma SOD $(P=$ 0.04 ) and tended to have increased whole-blood BHB concentrations $(P=0.06)$ compared with cows in POS (POS vs. CON). Cows in POS tended to have increased plasma albumin concentrations $(P=0.09)$ compared with cows in CON (POS vs. CON). There was a positive linear treatment effect for plasma glutamate dehydrogenase $(P=0.05)$ as concentration of adsorbent in the diet increased. A positive linear trend was present for plasma alanine aminotransferase $(P=0.06)$ as concentration of adsorbent in the diet increased. No treatment $x$ day interactions were observed for any blood variables $(P>0.11)$. 


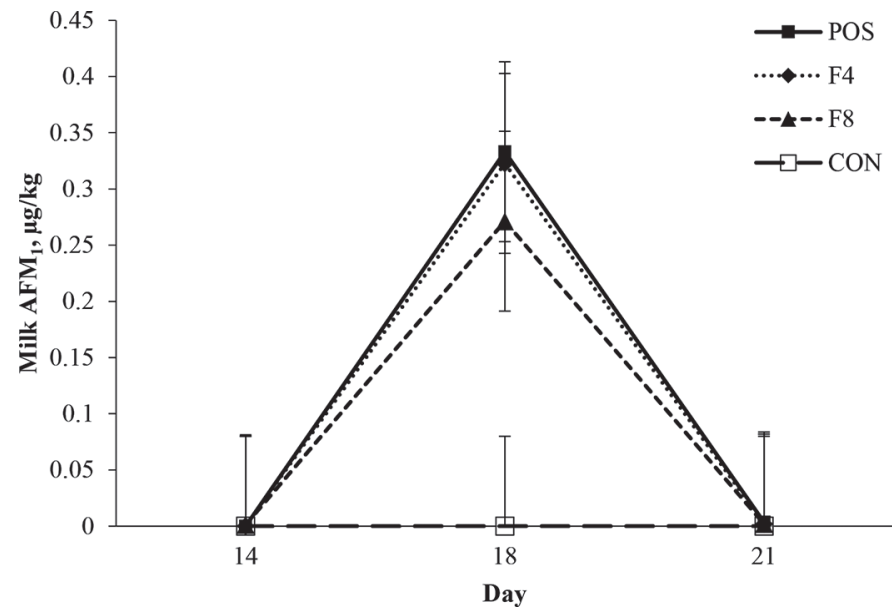

Figure 2. Least squares means and associated SEM for milk aflatoxin (AF) $\mathrm{M}_{1}$ response of Holstein cows in negative control without adsorbent $(\mathrm{CON})$, positive control without adsorbent (POS), treatment with $113 \mathrm{~g}$ of adsorbent (F4), and treatment with $227 \mathrm{~g}$ of adsorbent (F8). Samples were taken on d 14, 18, and 21 during the last week of each period.

\section{Hepatic Gene Expression}

Accession numbers, gene symbols, and forward and reverse sequences for all primers used are shown in Table 6. Hepatic gene expression data are given in Table 7. The expression of NFKB1 was greater in liver of cows in POS compared with cows in $\mathrm{CON}(P=$ 0.04 ; POS vs. CON). The expression of MTOR was greater in liver of cows in CON compared with cows in

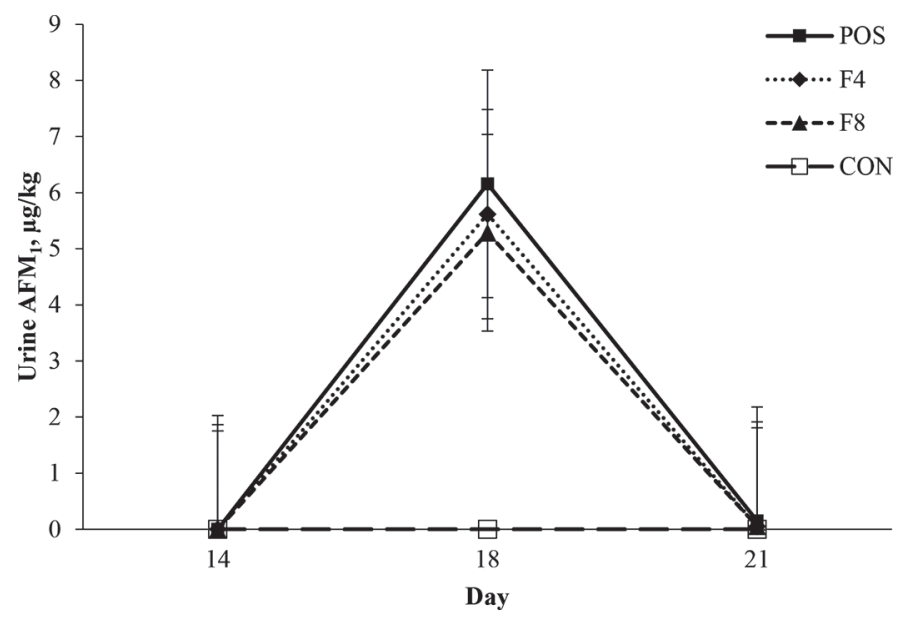

Figure 3. Least squares means and associated SEM for urine aflatoxin (AF) $\mathrm{M}_{1}$ response of Holstein cows in negative control without adsorbent $(\mathrm{CON})$, positive control without adsorbent (POS), treatment with $113 \mathrm{~g}$ of adsorbent (F4), and treatment with $227 \mathrm{~g}$ of adsorbent (F8). Samples were taken on d 14, 18, and 21 during the last week of each period.

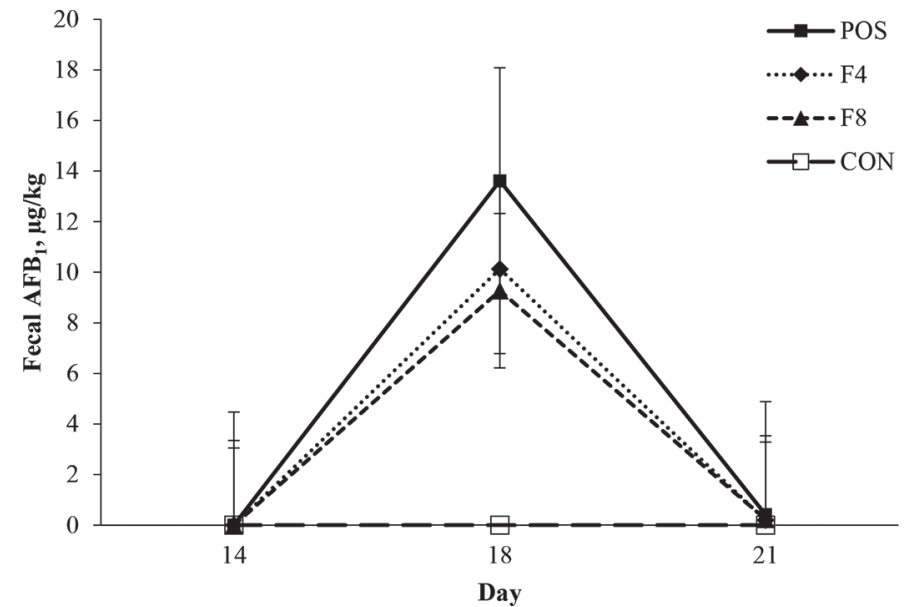

Figure 4. Least squares means and associated SEM for fecal aflatoxin (AF) $\mathrm{B}_{1}$ response of Holstein cows in negative control without adsorbent $(\mathrm{CON})$, positive control without adsorbent (POS), treatment with $113 \mathrm{~g}$ of adsorbent (F4), and treatment with $227 \mathrm{~g}$ of adsorbent (F8). Samples were taken on d 14, 18, and 21 during the last week of each period.

POS $(P=0.04 ;$ POS vs. CON $)$. A quadratic treatment effect occurred for GLUD1 expression in liver of cows as adsorbent concentration increased in the $\operatorname{diet}(P=$ 0.04). There was a positive linear trend for haptoglobin expression in liver of cows as adsorbent concentration increased in the $\operatorname{diet}(P=0.10)$.

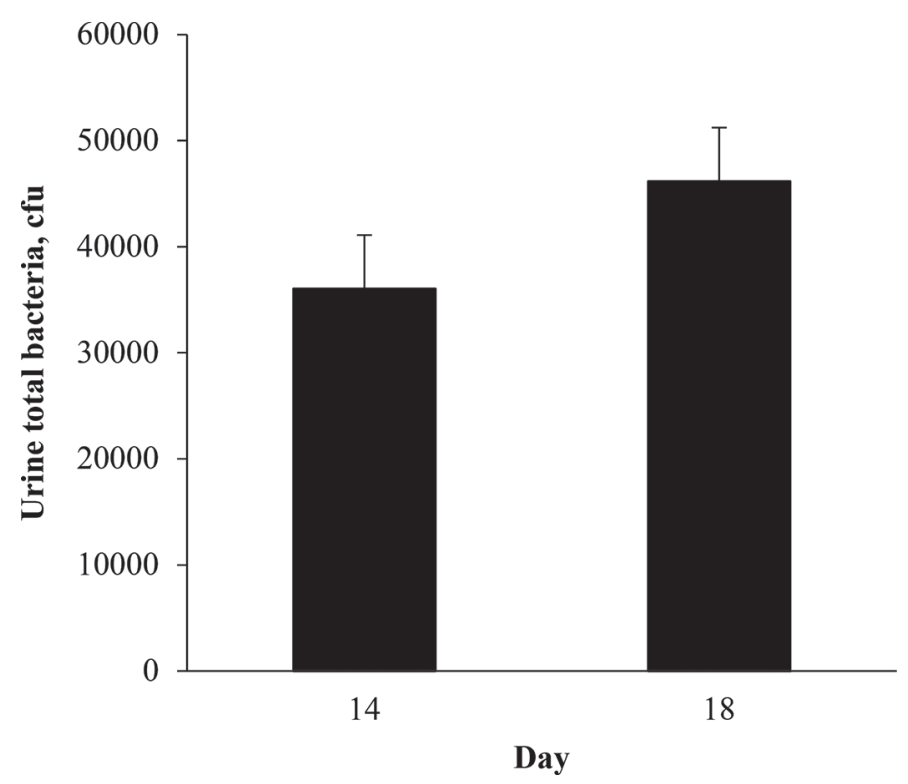

Figure 5. Least squares means and associated SEM for total bacteria counts in urine of Holstein cows on d 14 and 18 during the last week of each period. Treatment $(P=0.54)$, day $(P=0.05)$, and treatment $\times$ day $(P=0.99)$. 
Table 5. Least squares means and associated SEM for blood metabolites of Holstein cows during wk 3 of each period (measurement phase)

\begin{tabular}{|c|c|c|c|c|c|c|c|c|}
\hline Blood variable $^{1}$ & \multicolumn{4}{|c|}{ Treatment $^{2}$} & SEM & \multicolumn{3}{|c|}{$P$-value ${ }^{3}$} \\
\hline $\mathrm{BHB}, \mathrm{mg} / \mathrm{dL}$ & 0.45 & 0.45 & 0.47 & 0.51 & 0.03 & 0.06 & 0.59 & 0.70 \\
\hline Albumin, $\mathrm{g} / \mathrm{dL}$ & 3.63 & 3.65 & 3.64 & 3.59 & 0.02 & 0.09 & 0.77 & 0.40 \\
\hline Glucose, $\mathrm{mg} / \mathrm{dL}$ & 57.6 & 57.2 & 59.8 & 59.1 & 1.26 & 0.31 & 0.13 & 0.21 \\
\hline Serum amyloid $\mathrm{A}, \mu \mathrm{g} / \mathrm{mL}$ & 121 & 110 & 119 & 134 & 18.44 & 0.53 & 0.76 & 0.73 \\
\hline LPS binding protein, $\mu \mathrm{g} / \mathrm{mL}$ & 6.1 & 4.7 & 5.4 & 6.4 & 0.87 & 0.40 & 0.90 & 0.39 \\
\hline Glutamate dehydrogenase, U/L & 37.8 & 39.3 & 39.1 & 36.1 & 3.34 & 0.86 & 0.05 & 0.14 \\
\hline Alanine aminotransferase, $\mathrm{U} / \mathrm{L}$ & 28.0 & 28.7 & 28.9 & 28.1 & 1.46 & 0.90 & 0.06 & 0.50 \\
\hline$\gamma$-Glutamyl transferase, $\mathrm{U} / \mathrm{L}$ & 27.9 & 28.2 & 28.2 & 27.7 & 3.84 & 0.62 & 0.57 & 0.70 \\
\hline
\end{tabular}

${ }^{1}$ All samples were run on blood plasma except cholesterol (blood serum).

${ }^{2}$ Dietary treatments (TRT) were positive control diet [POS; without adsorbent $(0 \mathrm{~g})$ and with aflatoxin (AF) challenge], $113 \mathrm{~g}$ of adsorbent in diet (F4; with $113 \mathrm{~g}$ of adsorbent in a top dress), $227 \mathrm{~g}$ of adsorbent in diet (F8; with $227 \mathrm{~g}$ of adsorbent in a top dress), and negative control $\operatorname{diet}(\mathrm{CON}$; without adsorbent and no AF challenge). Top dress vehicle was $300 \mathrm{~g}$ of ground corn. Aflatoxin challenge: $100 \mu \mathrm{g}$ of $\mathrm{AF} / \mathrm{kg}$ of $\mathrm{DMI}$ of contaminated corn, based on average DMI of the last $3 \mathrm{~d}$ before the challenge.

${ }^{3}$ Contrasts were 1 = POS compared with CON; linear and quadratic effects of treatments POS ( $\left.0 \mathrm{~g}\right)$, F4 (113 g of adsorbent), and F8 (227 g of adsorbent). TRT $\times$ day interaction was not present $(P>0.11)$ for all variables.

${ }^{4}$ One unit is defined as the amount of enzyme needed to exhibit $50 \%$ dismutation of the superoxide radical.

${ }^{5}$ Glutathione peroxidase activity. One unit (nmol/min) is defined as the amount of enzyme that will cause the oxidation of $1.0 \mathrm{nmol}$ of NADPH to $\mathrm{NADP}^{+}$per minute at $25^{\circ} \mathrm{C}$.

\section{Liver Histology}

Odds ratios (OR) for effects of treatment on hepatocyte inflammation were determined (Table 8). When compared with cows in CON, cows in POS had greater $\mathrm{OR}$ for hepatocyte inflammation $(\mathrm{OR}=5.14, P=$ 0.05). When compared with cows in F8, cows in POS tended to have greater OR for hepatocyte inflammation $(\mathrm{OR}=4.60, P=0.07)$.

\section{DISCUSSION}

The objective of this study was to determine the effects of a commercially available aluminosilicate clay in a traditional lactation diet during an $\mathrm{AF}$ challenge $\left(\mathrm{AFB}_{1}\right)$ on the presence of $\mathrm{AFM}_{1}$ in milk and urine, $\mathrm{AFB}_{1}$ in feces, production responses, blood chemistry, and liver inflammatory markers of multiparous lactating Holstein cows. The hypothesis was that cows receiving aluminosilicate clay would experience lower AF excretion in milk, urine, and feces and would therefore exhibit lower oxidative stress than cows not receiving adsorbent.

No differences in DMI or feed efficiency among cows with or without an AF challenge were observed in the present study. Similarly, Xiong et al. (2015) reported no differences in DMI or feed efficiency for cows with or without an AF challenge. However, these results differ

Table 6. Accession number, gene symbol, and forward and reverse primer sequences $\left(5^{\prime}-3^{\prime}\right.$ used in real-time PCR) of genes analyzed in liver tissue

\begin{tabular}{llll}
\hline Accession no. & Symbol & Forward sequence & Reverse sequence \\
\hline BC151546.1 & ALB & AGTGCTGCACAGAGTCATTGGT & GGCTTTGGGTACATATGTTTCATCA \\
XM_010798596.2 & CYP1A2 & CAGTAAGGAGATGCTCAGTC & CTGTTCTTGTCAAAGTCCTGG \\
NM_001034034.2 & GAPDH & TGGAAAGGCCATCACCATCT & CCCACTTGATGTTGGCAG \\
NM_182652.2 & GLUD1 & CGTTTTGGTGCTAAATGTATTGCT & CATGTTGCAATTTGAAGTCTTCCA \\
NM_001040470.2 & HP & GGTTCGGAAAACCATCGCTA & CACTCGTGTCCCCTCCCTC \\
NM_001013587.1 & MDH2 & TCTGCATCATCTCAAATCCAGTTAAC & GTCACCCCGAAGATTTGTTG \\
XM_002694043 & MTOR & CCCCGATCGTGAAGTTATTTG & GTGTGCGTACAATCGGATGAA \\
NM_001076409.1 & NFKB1 & TTCAACCGGAGATGCCACTAC & ACACACGTAACGGAAACGAAATC \\
NM_001101152.2 & RPS9 & CCTCGACCAAGAGCTGAAG & CCTCCAGACCTCACGTTTGTTC \\
NM_001012673.1 & STAT5A & TCGCCACATTCTGTACAATGAAC & CTGGTTGATCTGAAGGTGTTTCTG \\
NM_173966.3 & TNFA & CCAGAGGGAAGAGCAGTCCC & TCGGCTACAACGTGGGCTAC \\
BC108205.1 & UXT & TGTGGCCCTTGGATATGGTT & GGTTGTCGCTGAGCTCTGTG \\
\hline
\end{tabular}


Table 7. Least squares means and associated SEM for liver gene expression response of Holstein cows during wk 3 of each period (measurement phase)

\begin{tabular}{|c|c|c|c|c|c|c|c|c|}
\hline \multirow[b]{2}{*}{ Gene $^{1}$} & \multicolumn{4}{|c|}{ Treatment $^{2}$} & \multirow[b]{2}{*}{ SEM } & \multicolumn{3}{|c|}{$P$-value ${ }^{3}$} \\
\hline & POS & $\mathrm{F} 4$ & F8 & $\mathrm{CON}$ & & $\begin{array}{c}\text { Contrast } \\
\text { (POS vs. CON) }\end{array}$ & $\begin{array}{l}\text { Linear } \\
\text { (TRT) }\end{array}$ & $\begin{array}{l}\text { Quad } \\
\text { (TRT) }\end{array}$ \\
\hline$A L B$ & 0.68 & 0.67 & 0.63 & 0.66 & 0.08 & 0.68 & 0.21 & 0.56 \\
\hline CYP1A2 & 0.84 & 0.86 & 0.81 & 0.83 & 0.09 & 0.88 & 0.70 & 0.56 \\
\hline GLUD1 & 0.64 & 0.74 & 0.67 & 0.68 & 0.07 & 0.33 & 0.45 & 0.04 \\
\hline$H P$ & 0.03 & 0.04 & 0.12 & 0.04 & 0.09 & 0.73 & 0.10 & 0.60 \\
\hline MDH2 & 0.79 & 0.77 & 0.78 & 0.79 & 0.06 & 0.99 & 0.74 & 0.76 \\
\hline MTOR & 0.96 & 1.05 & 1.11 & 1.19 & 0.06 & 0.04 & 0.33 & 0.64 \\
\hline NFKB1 & 0.78 & 0.73 & 0.76 & 0.70 & 0.05 & 0.04 & 0.59 & 0.30 \\
\hline STAT5A & 0.66 & 0.61 & 0.65 & 0.62 & 0.09 & 0.38 & 0.85 & 0.26 \\
\hline TNFA & 1.51 & 1.49 & 1.43 & 1.46 & 0.11 & 0.76 & 0.59 & 0.87 \\
\hline
\end{tabular}

${ }^{1}$ Samples that were analyzed were collected on d 18 of each period. $A L B=$ albumin; $C Y P 1 A 2=$ cytochrome P450-1A2; GLUD1 = glutamate dehydrogenase; $H P=$ haptoglobin; $M D H 2=$ malate dehydrogenase 2; $M T O R$ $=$ mechanistic target of rapamycin; NFKB1 = nuclear factor $\kappa \beta 1 ; S T A T 5 A=$ signal transducer and activator of transcription 5A; TNFA = tumor necrosis factor $\alpha$.

${ }^{2}$ Dietary treatments (TRT) were positive control diet [POS; without adsorbent $(0 \mathrm{~g})$ and with aflatoxin (AF) challenge], $113 \mathrm{~g}$ of adsorbent in diet (F4; with $113 \mathrm{~g}$ of adsorbent in a top dress), $227 \mathrm{~g}$ of adsorbent in diet (F8; with $227 \mathrm{~g}$ of adsorbent in a top dress), and negative control diet (CON; without adsorbent and no AF challenge). Top dress vehicle was $300 \mathrm{~g}$ of ground corn. Aflatoxin challenge: $100 \mu \mathrm{g}$ of AF/ $\mathrm{kg}$ of DMI of contaminated corn, based on average DMI of the last $3 \mathrm{~d}$ before the challenge.

${ }^{3}$ Contrasts were 1 = POS compared with CON; linear and quadratic effects of treatments POS (0 g), F4 (113 $\mathrm{g}$ of adsorbent), and F8 (227 $\mathrm{g}$ of adsorbent).

Table 8. Odds ratio (OR) of histological hepatocyte inflammation ${ }^{1}$ of Holstein cows on d 18 of each period

\begin{tabular}{llclc}
\hline Treatment $^{2}$ & Level & OR & $95 \% \mathrm{CI}^{3}$ & $P$-value \\
\hline POS & POS-F4 & 2.60 & $0.51-13.272$ & 0.25 \\
& POS-F8 & 4.60 & $0.90-23.66$ & 0.07 \\
& POS-CON $^{6}$ & 5.14 & $0.97-27.33$ & 0.05 \\
F4 & F4-F8 & 1.77 & $0.39-8.11$ & 0.46 \\
& F4-CON & 1.98 & $0.42-9.40$ & 0.39 \\
F8 & F8-CON & 1.12 & $0.24-5.30$ & 0.89 \\
\hline
\end{tabular}

${ }^{1}$ Hepatocyte inflammation classes at d 18 were based on the median value: high hepatocyte inflammation (HHAS) when score $\geq 1.25$ and low hepatocyte inflammation (LHAS) when score $<1.25$ (0-2 scale).

${ }^{2}$ Dietary treatments were positive control diet [POS; without adsorbent $(0 \mathrm{~g})$ and with aflatoxin (AF) challenge], $113 \mathrm{~g}$ of adsorbent in $\operatorname{diet}$ (F4; with $113 \mathrm{~g}$ of adsorbent in a top dress), $227 \mathrm{~g}$ of adsorbent in diet (F8; with $227 \mathrm{~g}$ of adsorbent in a top dress), and negative control diet (CON; without adsorbent and no AF challenge). Top dress vehicle was $300 \mathrm{~g}$ of ground corn. Aflatoxin challenge: $100 \mu \mathrm{g}$ of AF/ $\mathrm{kg}$ of DMI of contaminated corn, based on average DMI of the last 3 $\mathrm{d}$ before the challenge.

${ }^{3}$ Confidence interval derived from a binomial regression.

${ }^{4} \mathrm{POS}(\mathrm{n}=16$; HHAS $=12$, and LHAS $=4)$ and F4 $(\mathrm{n}=16$; HHAS $=9$, and LHAS $=7$ ).

${ }^{5} \mathrm{POS}(\mathrm{n}=16$; HHAS $=12$, and LHAS $=4)$ and F8 $(\mathrm{n}=16$; HHAS $=7$, and LHAS $=9$ ).

${ }^{6} \mathrm{POS}(\mathrm{n}=16 ;$ HHAS $=12$, and LHAS $=4)$ and CON $(\mathrm{n}=15 ;$ HHAS $=6$, and LHAS $=9)$.

${ }^{7} \mathrm{~F} 4(\mathrm{n}=16 ;$ HHAS $=9$, and LHAS $=7)$ and F8 $(\mathrm{n}=16 ;$ HHAS $=$ 7 , and LHAS $=9)$.

${ }^{8} \mathrm{~F} 4(\mathrm{n}=16 ;$ HHAS $=9$, and LHAS $=7)$ and CON $(\mathrm{n}=15 ;$ HHAS $=6$, and LHAS $=9)$.

${ }^{9} \mathrm{~F} 8(\mathrm{n}=16$; HHAS $=7$, and LHAS $=9)$ and CON $(\mathrm{n}=15$; HHAS $=6$, and LHAS $=9)$. from those seen in Pate and Cardoso (2018), in which AF-challenged cows had poorer feed efficiencies than cows without AF challenge. Previous studies have found that inclusion of adsorbents in a diet fed to cows receiving $\mathrm{AF}$ resulted in no difference in milk yield or even a decrease in milk yield (Queiroz et al., 2012; Ogunade et al., 2016; Weatherly et al., 2018). However, a positive linear treatment effect for FCM and ECM and a quadratic treatment effect for milk yield were observed in the present study with a $7.5 \%$ (F4) and $4.4 \%$ (F8) milk yield increase compared with POS. In the present study, a positive linear and a quadratic treatment effect were observed for lactose yield $(\mathrm{kg} / \mathrm{d})$. Sulzberger et al. (2017) reported a negative linear treatment effect on milk yield and a negative linear trend for lactose yield as adsorbent concentration increased in the diet. In the current study, the positive linear trend for ECM could be responsible for the increased lactose yield in adsorbent-treated cows. Additionally, in the current study, a positive quadratic treatment effect was observed for protein yield $(\mathrm{kg} / \mathrm{d})$.

As in previous studies, a lower milk $\mathrm{AFM}_{1}$ excretion was expected for cows receiving no AF (Xiong et al., 2015; Sulzberger et al., 2017; Pate and Cardoso, 2018). This was supported in the present study, as cows without an $\mathrm{AF}$ challenge had no $\mathrm{AFM}_{1}$ excretion or transfer in milk. Previous studies reported that cows that received clay during an AF challenge had lower concentrations of AF excreted in the milk, urine, and feces (Kutz et al., 2009; Kissell et al., 2013; Barrientos-Velazquez et 
al., 2016). Sulzberger et al. (2017) and Maki et al. (2016) both reported that milk $\mathrm{AFM}_{1}$ concentrations decreased as the concentration of clay included in the diet increased. Similar results were seen in the current study, as cows receiving an AF challenge and adsorbent had lower concentrations of $\mathrm{AFM}_{1}$ in milk and urine and lower concentrations of $\mathrm{AFB}_{1}$ in feces during the measurement phase (d 14, 18, and 21). Additionally, as the concentration of adsorbent given increased, a significant decrease in milk $\mathrm{AFM}_{1}$ proportion of $3 \%$ (F4) and 19\% (F8) at peak AF exposure (d 18) was observed. Previous in vitro experiments reported that adsorbents resulted in $\mathrm{AF}$ sequestering capacity of up to $100 \%$ (Lemke et al., 2001; Barrientos-Velazquez et al., 2016). However, due to inherent factors such as $\mathrm{pH}$, active site competition, and enzyme activity, decreased sequestering capacity is seen in vivo (BarrientosVelazquez et al., 2016). This information could explain why the milk, urine, and feces from cows treated with adsorbent still had elevated AF concentrations compared with cows in CON. A quadratic treatment effect was present for $\mathrm{AFM}_{1}$ transfer in milk. Additionally, in the current study $\mathrm{AFM}_{1}$ transference values were lower than those from previous research (Kutz et al., 2009; Weatherly et al., 2018). However, it is important to note that in the current study, transference data were calculated $1 \mathrm{~d}$ after the last AF challenge was given, whereas previous research calculated transference data on the same day that an AF challenge was given. Also, $\mathrm{AFM}_{1}$ transfer values were similar to those from Maki et al. (2016) when an adsorbent was added to the diet. No difference was observed for $\mathrm{AFM}_{1}$ excretion when adsorbent was added to the diet. Increased milk yield, FCM, and ECM when adsorbent was added to the diet could explain the result that $\mathrm{AFM}_{1}$ excretion did not decrease during the AF challenge.

There was an increase in urine total bacteria counts from d $14(36,030 \mathrm{cfu})$ to d $18(46,165 \mathrm{cfu})$ for all treatments. Although AF challenge is not explicitly related to SARA, comparisons between these conditions may be helpful in assessing gut inflammation during physiological stress. Khafipour et al. (2009) induced SARA (rumen $\mathrm{pH}<5.6$ ) in lactating Holstein cows and reported that blood plasma concentration of LPS, an immunogenic compound, was greater for cows experiencing a SARA challenge (0.52 endotoxin units $/ \mathrm{mL})$ compared with those without SARA challenge $(<0.5$ endotoxin units $/ \mathrm{mL})$. The authors of the aforementioned study suggested that the increase in circulating LPS was due to SARA-induced gut inflammation that was responsible for increased endothelium permeability (Khafipour et al., 2009). Similarly, one could speculate that in the current study, AF challenge caused gut in- flammation, which led to increased blood bacteria and, consequently, urine bacteria. However, the specific link between an AF challenge and increased total bacteria counts in urine is still to be determined.

Cows in POS had lower concentrations of serum cholesterol and a trend for lower concentration of $\mathrm{BHB}$ than cows in CON. Sulzberger et al. (2017) reported decreased total cholesterol concentrations when cows were challenged with AF as well as a trend for increased total cholesterol as concentration of adsorbent in the diet increased. Similar results were reported in rats, where serum cholesterol concentrations decreased when an AF challenge was administered (Abdel-Wahhab et al., 2002). Additionally, previous researchers reported that dairy goats challenged with AF had decreased BHB compared with goats not challenged with AF (Cheng et al., 2017). However, in other studies analyzing mitigation strategies during an $\mathrm{AF}$ challenge, no differences were reported in blood BHB or serum cholesterol concentrations (Pate and Cardoso, 2018). Differences between these experiments may be due to increased milk production in the current experiment. A downregulation in the MTOR gene was also present in cows that received an AF challenge compared with cows that did not receive an AF challenge. Activation of MTOR has been associated with increased lipogenesis ( $\mathrm{Li}$ et al., 2016; Liu et al., 2016). Xu et al. (2017) indicated that an upregulation in MTOR in Jersey cows fed high-grain diets as a challenge could be responsible for increased hepatic lipogenesis. In the current study, downregulation of MTOR for cows in POS could explain the decrease in serum cholesterol for this treatment. However, it is important to note that serum cholesterol and BHB concentrations were within normal bovine biological ranges $(77-240 \mathrm{mg} / \mathrm{dL}$ and $<1.2 \mathrm{mg} / \mathrm{dL}$, respectively; Lumsden et al., 1980), and biological relevance of these data must be carefully evaluated.

In the current study, SOD concentrations were lower for cows in POS compared with cows in CON. Similar results were reported by Xiong et al. (2015), where the concentration of blood SOD decreased as AF concentrations in the diet increased. However, Sulzberger et al. (2017) and Weatherly et al. (2018) reported that cows receiving AF tended to have greater concentrations of SOD in the circulation compared with cows without AF. Additionally, no differences in SOD concentration were seen in Pate and Cardoso (2018). This may be due to decreased DMI as a percentage of BW and, subsequently, AF intake as a percentage of $\mathrm{BW}$ in that study compared with the current study. The role of SOD is related to oxidative stress and maintaining normal cellular function in cattle, as SOD is involved in 
the antioxidant system (Bernabucci et al., 2002; Yuan et al., 2012; Machado et al., 2014). A lower blood SOD concentration in cows challenged with $\mathrm{AF}$, as seen in the current study, could indicate liver function suppression due to stress incurred by AF. Also, it is important to note that supplementation of aluminosilicate clay may have a restorative effect during AF challenge, as SOD concentration for F4 seemed similar to CON.

Serum albumin concentrations for cows in POS tended to be greater than that for cows in CON. Albumin plays an important role in $\mathrm{AFB}_{1}$ transport throughout the circulatory system (Wild et al., 1992; Lu et al., 2017). $\mathrm{Lu}$ et al. (2017) reported greater albumin concentrations for rats without adsorbent (oxidized tea phenols) compared with those that received adsorbent during an AF challenge. Pate and Cardoso (2018) reported a tendency for greater serum albumin concentrations for Holstein cows not challenged with AF compared with those that received the AF challenge. These data, along with data from the current experiment, may indicate an increased need for albumin to transport $\mathrm{AFB}_{1}$ throughout the body during an AF challenge. Contradictorily, previous research with chickens reported decreased albumin concentration when an AF challenge was present (Chattopadhyay et al., 1985; Hussain et al., 2016). Therefore, the authors of the current experiment suggest that further research be conducted regarding albumin and AF interaction in ruminants.

Glutamate dehydrogenase and alanine aminotransferase are indicators of liver functionality and inflammation (Weemhoff et al., 2017). Previous studies have reported that cows not receiving an AF challenge had greater serum glutamate dehydrogenase compared with cows receiving an AF challenge (Sulzberger et al., 2017). In the present study, there were no differences in plasma glutamate dehydrogenase or alanine aminotransferase between cows in POS and CON. This may be due to the extent and duration of AF exposure to cows in POS. Xiong et al. (2015) challenged cows with $\mathrm{AF}$ and increasing amounts of adsorbent in the diet and found no change in plasma glutamate dehydrogenase and alanine aminotransferase concentrations. However, in the current study, plasma glutamate dehydrogenase concentrations increased as amount of adsorbent in the diet increased, and a similar trend was observed for plasma alanine aminotransferase. In addition, there was a positive quadratic trend for GLUD1 expression in liver tissue. One could hypothesize that lower plasma glutamate dehydrogenase and alanine aminotransferase concentrations are indicators of liver suppression for cows in POS and that increasing adsorbent in the diet could negate these alterations.

Liver expression of NFKB1 was greater in cows receiving an AF challenge compared with those without an AF challenge. Similar results were observed in Pate and Cardoso (2018), where hepatic NFKB1 expression was greater in cows challenged with AF compared with cows without AF challenge. Additionally, $\mathrm{Xu}$ et al. (2017) reported increased hepatic NFKB1 expression when a grain challenge was fed to Holstein cows. Increased NFKB1 expression has been shown to regulate other inflammatory genes, such as TNFA and IL6, which are proinflammatory cytokines (Baker et al., 2011). Although TNFA was not directly upregulated during the AF challenge, NFKB1 upregulation could indicate an increase in a hepatic inflammatory mechanism occurring during an AF challenge. Additionally, length of an AF challenge could affect the degree to which the proposed inflammatory mechanism occurs. Further research regarding extent and duration of AF exposure on hepatic inflammatory pathways is necessary to validate this postulation.

Hepatocyte inflammation was also evaluated in the current study via histological analysis on hematoxylin and eosin stained liver tissue based on grading scores adapted from Ishak et al. (1995). Hepatic inflammation score was categorized at the median concentration value of score 1.25 as high or low. Even though dichotomization can reduce total information, this strategy allowed for exploration of the nonlinear association of hepatic activity scores that have reduced variation (Ishak et al., 1995). An OR $>1$ indicated that cows challenged with AF without adsorbent (POS) had increased hepatocyte inflammation (i.e., gray pallor or swelling) compared with cows in CON. Cows in POS also tended to have increased hepatocyte inflammation compared with cows in F8. In the current study, increased hepatocyte inflammation for cows in POS compared with cows in $\mathrm{CON}$ indicated that the AF challenge affected liver health and functionality. In addition, hepatocyte inflammation tended to decrease when an adsorbent was implemented into the diet at $227 \mathrm{~g}$ (F8). These data potentiate the hypothesis that increased adsorbent in the diet protects liver and immunological functionality during AF exposure.

\section{CONCLUSIONS}

The results from the present study indicate that AF can have a negative effect on cow milk production and ECM. This may be a result of reduced function and increased inflammation of the liver as suggested by changes in blood metabolites and liver gene expression. The adsorbent used in this study had a positive effect on milk production and hepatocyte inflammation as well as AF transfer in milk, urine, and feces. The effect of the adsorbent on blood metabolites and liver gene expression was neither hindered nor improved. Still to 
be determined are the responses from dairy cows to $\mathrm{AF}$ challenges with different duration of $\mathrm{AF}$ exposure and concentration of $\mathrm{AF}$ in the diet.

\section{ACKNOWLEDGMENTS}

This project was partially supported by PMI Nutritional Additives (Arden Hills, MN). We thank Ajinomoto Heartland Inc. (Chicago, IL) for the donation of Ajipro-L Generation 2, Adisseo (Alpharretta, GA) for the donation of Smartamine M, and Perdue AgriBusiness (Salisbury, MD) for the donation of ProVAAl AADvantage during the course of the experiment. Special appreciation is extended to the Dairy Focus Team at the University of Illinois, along with the University of Illinois Dairy Research Unit staff for helping with data collection and cow care.

\section{REFERENCES}

Abdel-Wahhab, M. A., S. A. Nada, and F. A. Khalil. 2002. Physiological and toxicological responses in rats fed aflatoxin-contaminated diet with or without sorbent materials. Anim. Feed Sci. Technol. 97:209-219.

Abrar, M., F. M. Anjum, M. S. Butt, I. Pasha, M. A. Randhawa, F. Saeed, and K. Waqas. 2013. Aflatoxins: Biosynthesis, occurrence, toxicity, and remedies. Crit. Rev. Food Sci. Nutr. 53:862-874.

AOAC International. 1995a. Official method 934.01. Moisture in animal feed. Pages 23-26 in Official Methods of Analysis. 16th ed. Vol. 2. AOAC International, Arlington, VA.

AOAC International. 1995b. Official method 972.16. Fat, lactose, protein, and solids in milk. Mid-infrared spectroscopic method. Pages 2-5 in Official Methods of Analysis. 16th ed. Vol. 2. AOAC International, Arlington, VA.

Applebaum, R. S., R. E. Brackett, D. W. Wiseman, and E. H. Marth. 1982. Aflatoxin: Toxicity to dairy cattle and occurrence in milk and milk products: A review. J. Food Prot. 45:752-777.

Baker, R. G., M. S. Hayden, and S. Ghosh. 2011. NF-кB, inflammation, and metabolic disease. Cell Metab. 13:11-22.

Barrientos-Velazquez, A. L., S. Arteaga, J. B. Dixon, and Y. J. Deng. 2016. The effects of $\mathrm{pH}$, pepsin, exchange cation, and vitamins on aflatoxin adsorption on smectite in simulated gastric fluids. Appl. Clay Sci. 120:17-23.

Bernabucci, U., L. Colavecchia, P. P. Danieli, L. Basiricò, N. Lacetera, A. Nardone, and B. Ronchi. 2011. Aflatoxin B1 and fumonisin B1 affect the oxidative status of bovine peripheral blood mononuclear cells. Toxicol. In Vitro 25:684-691.

Bernabucci, U., B. Ronchi, N. Lacetera, and A. Nardone. 2002. Markers of oxidative status in plasma and erythrocytes of transition dairy cows during hot season. J. Dairy Sci. 85:2173-2179.

Betrán, J., G. Odvody, K. Mayfield, and T. Isakeit. 2005. Breeding corn to reduce preharvest aflatoxin contamination. Pages 353-378 in Aflatoxin and Food Safety. H. K. Abbas, ed. CRC Press, Boca Raton, FL.

Chattopadhyay, S. K., P. K. Taskar, O. Schwabe, Y. T. Das, and H. D. Brown. 1985. Clinical and biochemical effects of aflatoxin in feed ration of chicks. Cancer Biochem. Biophys. 8:67-75.

Cheng, J., S. Huang, C. Fan, N. Zheng, Y. Zhang, S. Li, and J. Wang. 2017. Metabolomic analysis of alterations in lipid oxidation, carbohydrate and amino acid metabolism in dairy goats caused by exposure to aflotoxin B1. J. Dairy Res. 84:401-406.

European Commission. 2006. Commission Regulation (EC) No 1881/2006 of 19 December 2006 setting maximum levels for certain contaminants in foodstuffs. Off. J. L364:5-24.
FAO (Food and Agriculture Organization). 2004. Worldwide Regulations for Mycotoxins in Food and Feed in 2003. FAO, Rome, Italy.

FDA (Food and Drug Administration). 1994. Sec. 683.100, Action Levels for Aflatoxins in Animal Feeds (CPG 7126.33). Accessed Jun. 21, 2018. https://www.fda.gov/iceci/compliancemanuals/ compliancepolicyguidancemanual/ucm074703.htm.

Ferguson, J. D., D. T. Galligan, and N. Thomsen. 1994. Principal descriptors of body condition score in Holstein cows. J. Dairy Sci. 77:2695-2703.

Haerr, K. J., N. M. Lopes, M. N. Pereira, G. M. Fellows, and F. C. Cardoso. 2015. Corn silage from corn treated with foliar fungicide and performance of Holstein cows. J. Dairy Sci. 98:8962-8972.

Hussain, Z., H. U. Rehman, S. Manzoor, S. Tahir, and M. Mukhtar. 2016. Determination of liver and muscle aflatoxin B1 residues and select serum chemistry variables during chronic aflatoxicosis in broiler chickens. Vet. Clin. Pathol. 45:330-334.

Ishak, K., A. Baptista, L. Bianchi, F. Callea, J. De Groote, F. Gudat, H. Denk, V. Desmet, G. Korb, R. N. M. MacSween, M. J. Phillips, B. G. Portmann, H. Poulsen, P. J. Scheuer, M. Schmid, and H. Thaler. 1995. Histological grading and staging of chronic hepatitis. J. Hepatol. 22:696-699.

Jiang, Y., I. M. Ogunade, D. H. Kim, X. Li, A. A. Pech-Cervantes, K. G. Arriola, A. S. Oliveira, J. P. Driver, L. F. Ferraretto, C. R. Staples, D. Vyas, and A. T. Adesogan. 2018. Effect of adding clay with or without a Saccharomyces cerevisiae fermentation product on the health and performance of lactating dairy cows challenged with dietary aflatoxin $\mathrm{B}_{1}$. J. Dairy Sci. 101:3008-3020.

Kabak, B., A. D. W. Dobson, and I. Var. 2006. Strategies to prevent mycotoxin contamination of food and animal feed: A review. Crit. Rev. Food Sci. Nutr. 46:593-619.

Kalebich, C. C., and F. C. Cardoso. 2017. Effects of foliar fungicide application on corn plants on the composition of corn silage for ruminant diets. J. Anim. Res. Nutr. 2:5-15.

Khafipour, E., D. O. Krause, and J. C. Plaizier. 2009. Alfalfa pelletinduced subacute ruminal acidosis in dairy cows increases bacterial endotoxin in the rumen without causing inflammation. J. Dairy Sci. 92:1712-1724.

Khan, M. J., C. B. Jacometo, M. Vailati Riboni, E. Trevisi, D. E. Graugnard, M. N. Corrêa, and J. J. Loor. 2015. Stress and inflammatory gene networks in bovine liver are altered by plane of dietary energy during late pregnancy. Funct. Integr. Genomics 15:563-576.

Kissell, L., S. Davidson, B. A. Hopkins, G. W. Smith, and L. W. Whitlow. 2013. Effect of experimental feed additives on aflatoxin in milk of dairy cows fed aflatoxin-contaminated diets. J. Anim. Physiol. Anim. Nutr. (Berl.) 97:694-700.

Kononoff, P. J., A. Heinrichs, and D. Buckmaster. 2003. Modification of the Penn State forage and total mixed ration particle separator and the effects of moisture content on its measurements. J. Dairy Sci. 86:1858-1863.

Kutz, R. E., J. Sampson, L. Pompeu, D. Ledoux, J. Spain, M. VazquezAnon, and G. Rottinghaus. 2009. Efficacy of Solis, NovasilPlus, and MTB-100 to reduce aflatoxin M1 levels in milk of early to mid lactation dairy cows fed aflatoxin B1. J. Dairy Sci. 92:3959-3963.

Lemke, S. L., S. E. Ottinger, K. Mayura, C. L. Ake, K. Pimpukdee, N. Wang, and T. D. Phillips. 2001. Development of a multi-tiered approach to the in vitro prescreening of clay-based enterosorbent. Anim. Feed Sci. Technol. 93:17-29.

Li, S., A. Hosseini, M. Danes, C. Jacometo, J. Liu, and J. J. Loor. 2016. Essential amino acid ratios and mTOR affect lipogenic gene networks and miRNA expression in bovine mammary epithelial cells. J. Anim. Sci. Biotechnol. 7:44.

Littell, R. C. 2002. Analysis of unbalanced mixed model data: A case study comparison of ANOVA versus REML/GLS. J. Agric. Biol. Environ. Stat. 7:472-490.

Liu, T. Y., X. Q. Xiong, X. S. Ren, M. X. Zhao, C. X. Shi, J. J. Wang, Y. B. Zhou, F. Zhang, Y. Han, X. Y. Gao, Q. Chen, Y. H. Li, Y. M. Kang, and G. Q. Zhu. 2016. FNDC5 alleviates hepatosteatosis by restoring AMPK/mTOR-mediated autophagy, fatty acid oxidation, and lipogenesis in mice. Diabetes 65:3262-3275. 
Lu, H., F. Liu, Q. Zhu, M. Zhang, T. Li, J. Chen, Y. Huang, X. Wang, and J. Sheng. 2017. Aflatoxin B1 can be complexed with oxidised tea polyphenols and the absorption of the complexed aflatoxin B1 is inhibited in rats. J. Sci. Food Agric. 97:1910-1915.

Lumsden, J. H., K. Mullen, and R. Rowe. 1980. Hematology and biochemistry reference values for female Holstein cattle. Can. J. Comp. Med. 44:24-31.

Machado, V. S., G. Oikonomou, S. Lima, M. Bicalho, C. Kacar, C Foditsch, M. Felippe, R. Gilbert, and R. Bicalho. 2014. The effect of injectable trace minerals (selenium, copper, zinc, and manganese) on peripheral blood leukocyte activity and serum superoxide dismutase activity of lactating Holstein cows. Vet. J. 200:299-304.

Maki, C. R., A. Thomas, S. Elmore, A. Romoser, R. Harvey, H Ramirez-Ramirez, and T. Phillips. 2016. Effects of calcium montmorillonite clay and aflatoxin exposure on dry matter intake, milk production, and milk composition. J. Dairy Sci. 99:1039-1046.

Mitchell, N. J., E. Bowers, C. Hurburgh, and F. Wu. 2016. Potential economic losses to the USA corn industry from aflatoxin contamination. Food Addit. Contam. A Chem. Anal. Control Expo. Risk. Assess. 33:540-550.

Moschini, M., A. Gallo, G. Piva, and F. Masoero. 2008. The effects of rumen fluid on the in vitro aflatoxin binding capacity of different sequestering agents and in vivo release of the sequestered toxin. Anim. Feed Sci. Technol. 147:292-309.

NRC. 2001. Nutrient Requirements of Dairy Cattle. 7th rev. ed. Natl. Acad. Press, Washington, DC.

Ogunade, I. M., K. G. Arriola, Y. Jiang, J. P. Driver, C. R. Staples, and A. T. Adesogan. 2016. Effects of 3 sequestering agents on milk aflatoxin M1 concentration and the performance and immune status of dairy cows fed diets artificially contaminated with aflatoxin B1. J. Dairy Sci. 99:6263-6273.

Pate, R. T., and F. C. Cardoso. 2018. Injectable trace minerals (selenium, copper, zinc, and manganese) alleviate inflammation and oxidative stress during an aflatoxin challenge in lactating multiparous Holstein cows. J. Dairy Sci. 101:8532-8543.

Queiroz, O. C., J. H. Han, C. R. Staples, and A. T. Adesogan. 2012. Effect of adding a mycotoxin-sequestering agent on milk aflatoxin $\mathrm{M}_{1}$ concentration and the performance and immune response of dairy cattle fed an aflatoxin $\mathrm{B}_{1}$-contaminated diet. J. Dairy Sci. 95:5901-5908.

Riboni, M., S. Meier, N. V. Priest, C. R. Burke, J. K. Kay, S. McDougall, M. D. Mitchell, C. G. Walker, M. Crookenden, A. Heiser, J. R. Roche, and J. J. Loor. 2015. Adipose and liver gene expression profiles in response to treatment with a nonsteroidal antiinflammatory drug after calving in grazing dairy cows. J. Dairy Sci. 98:3079-3085.
Shi, J., J. He, J. Lin, X. Sun, F. Sun, C. Ou, and C. Jiang. 2016 Distinct response of the hepatic transcriptome to aflatoxin $\mathrm{B}_{1}$ induced hepatocellular carcinogenesis and resistance in rats. Sci. Rep. 6:31898.

Shrestha, G. R., and A. U. Mridha. 2015. Detection and quantitation of aflatoxin for the diagnosis of Aspergillus flavus. Nepal J. Biotechnol. 3:6-9.

Silvestre, F. T., T. S. Carvalho, P. C. Crawford, J. E. Santos, C. R. Staples, T. Jenkins, and W. W. Thatcher. 2011. Effects of differential supplementation of fatty acids during the peripartum and breeding periods of Holstein cows: II. Neutrophil fatty acids and function, and acute phase proteins. J. Dairy Sci. 94:2285-2301.

Sulzberger, S. A., S. Melnichenko, and F. Cardoso. 2017. Effects of clay after an aflatoxin challenge on aflatoxin clearance, milk production, and metabolism of Holstein cows. J. Dairy Sci. 100:18561869 .

Weatherly, M. E., R. T. Pate, G. E. Rottinghaus, F. O. Roberti Filho, and F. C. Cardoso. 2018. Physiological responses to a yeast and clay-based adsorbent during an aflatoxin challenge in Holstein cows. Anim. Feed Sci. Technol. 235:147-157.

Weemhoff, J. L., B. L. Woolbright, R. E. Jenkins, M. R. McGill, M. R. Sharpe, J. C. Olson, D. J. Antoine, S. C. Curry, and H. Jaeschke. 2017. Plasma biomarkers to study mechanisms of liver injury in patients with hypoxic hepatitis. Liver Int. 37:377-384.

Whitlow, L. W., and W. M. Hagler. 2005. Mycotoxins in dairy cattle: Occurrence, toxicity, prevention and treatment. Pages 127-138 in Proc. Southwest Nutr. Conf., University of Arizona, Tucson.

Wild, C. P., G. J. Hudson, G. Sabbioni, B. Chapot, A. J. Hall, G. N. Wogan, H. Whittle, R. Montesano, and J. D. Groopman. 1992. Dietary intake of aflatoxins and the level of albumin-bound aflatoxin in peripheral blood in The Gambia, West Africa. Cancer Epidemiol. Biomarkers Prev. 1:229-234.

Xiong, J. L., Y. Wang, T. Nennich, Y. Li, and J. Liu. 2015. Transfer of dietary aflatoxin B1 to milk aflatoxin M1 and effect of inclusion of adsorbent in the diet of dairy cows. J. Dairy Sci. 98:2545-2554.

Xu, T., F. C. Cardoso, A. Pineda, E. Trevisi, X. Shen, F. Rosa, J. S. Osorio, and J. J. Loor. 2017. Grain challenge affects systemic and hepatic molecular biomarkers of inflammation, stress, and metabolic responses to a greater extent in Holstein than Jersey cows. J. Dairy Sci. 100:9153-9162.

Yuan, K., R. Shaver, S. Bertics, M. Espineira, and R. Grummer. 2012. Effect of rumen-protected niacin on lipid metabolism, oxidative stress, and performance of transition dairy cows. J. Dairy Sci. 95:2673-2679. 